\title{
GROWTH PERFORMANCE AND CARCASS TRAITS OF GOATS FED WITH OIL PALM BY- PRODUCTS BASED FEED PELLET
}

\author{
NUR ATIKAH IBRAHIM*; WAN NOORAIDA WAN MOHAMED*; 'ABIDAH MD NOH” \\ and MOOKIAH SAMINATHAN*
}

\begin{abstract}
The study was conducted to develop a nutrient-balanced goat feed pellet from oil palm by-products and to assess the effects of the feed pellet on growth performance and carcass traits of Katjang goats. Treatment groups consisted of oil palm by-products based (OPB), control without addition of oil palm by-products control (CNT) and commercial (COM) pellets. Twelve 12-month-old Katjang goats were assigned to the three treatment groups and subjected to 14-weeks of feeding trial. Each group was offered 1.5\% body weight (BW) of respective pellets and ad libitum supply of Napier grass. Feed intake (FI) was recorded daily and the BW of the goats was recorded weekly. At the end of the feeding trial, all goats were slaughtered for carcass traits study. All treatment groups showed no significant difference in BW increment $(p=0.51)$ and average daily gain $(A D G)(p=0.94)$. There were no significant differences ( $p>0.05)$ between the treatment groups for carcass traits parameters. As a conclusion, the OPB pellet has shown to contain complete nutrient for goat's diet and was comparable to the COM feed pellet in terms of growth performance of Katjang goat. The inclusion of oil palm by-products in the feed formulation did not adversely affect the carcass traits of the goats.
\end{abstract}

\section{Keywords: carcass traits, goat feed pellet, growth performance, oil palm by-products.}

Received: 10 February 2020; Accepted: 9 July 2020; Published online: 22 September 2020.

\section{INTRODUCTION}

Utilisation of local resources is one of the approaches to support the growing productivity and sustainability in agriculture industry (Rodriguez and Preston, 1997). Sontakke et al. (2014) described that the utilisation of the agricultural by-products not only could reduce the overall feed cost but could also decrease the competition for food between human and animals. Oil palm plantations in Malaysia covert a total of 5.81 million hectares in 2017 (MPOB, 2018). Crude palm oil (CPO) production for 2018 was 19.52 million tonnes (Kushairi et al., 2018). The

\footnotetext{
Malaysian Palm Oil Board,

6 Persiaran Institusi, Bandar Baru Bangi,

43000 Kajang, Selangor, Malaysia.

E-mail: atikah.ibrahim@mpob.gov.my
}

huge oil palm plantation area and the volume of $\mathrm{CPO}$ production annually have contributed to the increase of waste and by-products. Palm oil industry produces approximately $21.625 \mathrm{t} \mathrm{ha}^{-1}$ of solid biomass annually, which consists of oil palm fronds (OPF), 78\%; empty fruit bunches (EFB), 9\%; mesocarp fibre (PPF), 6\%; oil palm trunks (OPT), 5\%; and palm kernel shell, 2\% (Hosseini et al., 2015).

Most of the oil palm by-products have great potential to be utilised as ingredients in compound ruminant feeds. The proximate composition of the oil palm by-products is presented in Table 1. However, some of the by-products need further processing before they can be used effectively in livestock ration (Mohamed et al., 2012). OPF can be utilised as a satisfactory alternative roughage source for ruminants. The OPF inclusion into the ruminant diet can be either as freshly chopped, silage or 
treated with other physical methods (Sudaryanto, 2017). EFB is a solid residue produced in abundance at oil palm mill after the oil extraction process. At present, EFB is widely used as organic mulch at the plantation, pulp for making paper, wood composite products and fibreboard (Abdullah and Sulaiman, 2013). Although these practices contribute to EFB disposal, there are still plenty of EFB available that can be used for other purposes, for instance as a raw material in ruminant ration. Yet, information on its utilisation as animal feed is very limited (Ginting et al., 2018).

In crushing plant, palm kernels are crushed to yield crude palm kernel oil and the by-product is the palm kernel cake (PKC). The production of PKC from this process is around 50\% of the palm kernel. As one of the major world's producer of palm oil, Malaysia produces more than 2 million tonnes of PKC annually, much of which is exported to Europe, New Zealand, Korea, China and other countries (MPOB Annual Report, 2016). The crude protein (CP) content in PKC ranges between 12\%-18\%, making it suitable to be utilised as a protein source for ruminant feed, mostly in beef and dairy cattle feed (Fereira et al., 2012; Tipu et al., 2014; Pimentel et al., 2015).

CPO refining process produces about $5 \%$ palm fatty acid distillates (PFAD), another by-product. PFAD is a readily available, relatively stable to oxidative rancidity and has considerable nutritive value, especially as fat supplement for livestock (Tomkins and Drackley, 2010). The primary market for PFAD in the livestock feed industry is as ruminant diets, either as hydrogenated fatty acids or as calcium soap (Palmquist, 2004). The use of PFAD in animal feed formulation is a practical, costeffective and safe approach to produce good growth performance without any negative effects (AliyuPaiko and Hashim, 2012).

Goat and sheep farming industry in Malaysia is small. Thus, Malaysia still depends on the import of mutton and lamb from other countries such as
Australia, New Zealand and Indonesia (Meat and Livestock Australia, 2018). As compared to poultry $(103.33 \%)$, eggs $(119.06 \%)$ and beef cattle $(23.42 \%)$, the goat's self-sufficiency level (SSL) in 2017 only reached $11.41 \%$ (DVS, 2018). The main factor contributing to the low goat's SSL is the lack of local quality feed, thus, most of the feed ingredients have to be imported at higher price, leading to the unsustainable production of meat throughout the year.

Malaysia imports more than $70 \%$ of raw materials annually to support the animal feed industry, including $2000 \mathrm{t}$ and $1000 \mathrm{t}$ of corn and soyabean meal, respectively. Ministry of Agriculture and Food Industries Malaysia (2016) reported that the value of imported animal feed in Malaysia was almost RM6.7 billion in 2016. To develop domestic ruminant industry, there is a need to improve and produce sufficient feed resources to support the production of these animals. By-products from the Malaysian oil palm industry are seen as promising alternative components for ruminant feed as they are cost-effective and are locally available throughout the year. It is hypothesised that inclusion of oil palm by-products in the feed formulation can provide adequate nutrients for goats to support their growth. Thus, the objectives of this study were to develop a nutrient-balanced goat feed formulation using oil palm by-products and to evaluate the effects of the formulated pellet on the growth performance and carcass traits of Katjang goats.

\section{MATERIALS AND METHODS}

\section{Animals and Materials}

Katjang goats, raw materials for feed production (corn, soyabean meal, rice bran, PKC, EFB, PFAD and others) and commercial feed were purchased from local suppliers. OPF was obtained from MPOB Keratong Oil Palm Plantation, Pahang, Malaysia.

TABLE 1. PROXIMATE COMPOSITION OF OIL PALM BY-PRODUCTS

\begin{tabular}{lccc}
\hline Proximate analysis & OPF $^{\mathbf{a}}$ & PKC $^{\mathbf{b}}$ & EFB $^{\mathbf{c}}$ \\
\hline Dry matter (DM) & 36.4 & $88.0-94.5$ & - \\
Ash (\% DM) & 6.6 & $3.0-12.0$ & - \\
Crude fat (\% DM) & 1.2 & $5.0-8.0$ & 3.2 \\
Crude protein (\% DM) & 5.8 & $14.5-19.6$ & 3.7 \\
Crude fibre (\% DM) & 44.8 & $13.0-20.0$ & 48.8 \\
Nitrogen free extract (NFE) (\%) & 43.3 & $46.7-58.8$ & - \\
\hline
\end{tabular}

Note: OPF - oil palm frond; PKC - palm kernel cake; EFB - empty fruit bunch.

aAdapted from Zahari and Alimon (2005).

${ }^{\mathrm{b}}$ Adapted from Alimon (2004).

'Adapted from Zahari et al. (2003). 


\section{Pellet Formulation}

Two types of pellets were formulated to meet maintenance requirement for growing goats in accordance with the guidelines of nutrient requirements of small ruminants (NRC, 1981) as follows: control (CNT) pellet was formulated without using oil palm by-products based ingredients, and oil palm by-products based (OPB) pellet was formulated using OPF, PKC, EFB and PFAD. The other ingredients that were used in the pellet formulation are presented in Table 2. Another type of pellet was the commercial pellet (COM) purchased from a local supplier. Both CNT and OPB pellets were formulated to be isocaloric and isonitrogenic with COM pellet using New Century ${ }^{\mathrm{TM}}$ formulation software (FORMAT International, USA).

\section{Proximate Analysis}

The dry matter (DM), moisture, ash, $\mathrm{CP}$, crude fat, crude fibre (CF) and gross energy (GE) of the pellet samples were analysed according to the Association of Official Analytical Chemist (AOAC, 1990) procedures. Organic matter was calculated based on ash content (100 - ash content). Nitrogen free extract (NFE) was calculated using the equation below, as described by McDonald et al. (2010):

$$
\begin{aligned}
\operatorname{NFE}(\%)= & 100 \%-(\text { moisture } \%+\text { ash } \% \\
& + \text { crude fat } \%+\text { crude protein } \% \\
& + \text { crude fibre } \%)
\end{aligned}
$$

\section{Feeding Trial and Growth Performance}

The experimental design was a completely randomised design with three treatment groups that corresponded to three different types of pellets; either CNT, COM and OPB with four goats per treatment group. Twelve male Katjang goats of 12-month-old with initial body weight (BW) of about $14.7 \pm 1.1 \mathrm{~kg}$ were randomly assigned to one of the treatment groups. The Katjang goats were kept in individual pens of $1.8 \times 1.8 \mathrm{~m}$ with free access to water. Each group was fed twice daily with $1.5 \%$ BW of respective pellets and ad libitum supply of Napier grass. The goats were allowed for two weeks of adaptation period to adapt to the experimental conditions and diet prior to the 14-weeks of feeding trial.

The goats were weighed on the first day of the feeding trial and followed by weekly weighing before the morning feeding to determine the BW of the animals. Feed intake (FI) of each goat was recorded daily based on the amount of feed offered and refused. The amount of feed offered was adjusted weekly based on changes in BW of the goats. The average daily gain (ADG) was calculated by dividing the difference between initial and final BW by the period of feeding trial.

\section{Slaughter and Sampling}

At the end of the feeding trial, all goats were fasted for $24 \mathrm{hr}$ with free access to water before slaughtering. The goats were weighed again before being slaughtered and recorded as slaughter weight. The slaughtering was done according to Halal method outlined in MS 1500:2009 (Department of Standard Malaysia, 2009). Each carcass was first weighed as hot carcass. Subsequently, the pelt, head, internal organs (lung and trachea, liver and kidney) and internal fats including peritoneal and mesenteric, kidney, channel, and heart fats were weighed separately. Each carcass was then chilled for $24 \mathrm{hr}$ at $4^{\circ} \mathrm{C}$. The next day, chilled carcasses were reweighed and were split into two equal halves (right and left). The cuts were weighed and expressed

TABLE 2. INGREDIENTS OF OIL PALM BY-PRODUCTS BASED AND CONTROL PELLETS

\begin{tabular}{lcc}
\hline Ingredient (\%) & OPB & CNT \\
\hline Corn & 18.0 & 19.0 \\
Soyabean meal & 16.0 & 18.0 \\
Rice bran & 11.0 & 20.0 \\
Oil palm by-products (consists of PKC, OPF, EFB and PFAD) & 49.6 & - \\
Rice straw & - & 35.0 \\
Soyabean oil & - & 2.7 \\
Molasses & 3.50 & 4.00 \\
Salt & 0.50 & 0.50 \\
Limestone & 1.50 & 0.25 \\
Dicalcium phosphate & - & 0.25 \\
Vitamin mineral premix & 0.25 & 0.30 \\
\hline
\end{tabular}

Note: OPB - oil palm by-products based formulated pellet; CNT - pellet without oil palm by-product inclusion; PKC - palm kernel cake; OPF - oil palm frond; EFB - empty fruit bunch; PFAD - palm fatty acid distillates. 
as percentage of the total weight of the carcasses. Each cut was then further divided into meat, bone, and fat and the data was used to calculate carcass composition.

\section{Statistical Analysis}

Statistical analysis was performed using the Statistical Analysis System (SAS) statistical software package, version 9.1.3 (SAS Institute Inc., USA). Data obtained from all analytical parameters were analysed using one way analysis of variance (ANOVA), with significant differences determined by Duncan's new multiple range test. Statistical significance was considered at $p<0.05$.

\section{RESULTS AND DISCUSSION}

\section{Proximate Analysis of Feed Pellets}

The proximate composition of all pellets is shown in Table 3. The oil palm by-products in OPB pellet was formulated to contain a similar level of $\mathrm{CP}$ (isonitrogenous) and GE (isocaloric) content to CNT and COM pellets. OPB has been shown to contain complete nutrients for goat diet in accordance with the goat's nutrient requirements and was comparable to the COM pellet.

\section{Growth Performance}

Growth performance of Katjang goats fed with different pellets is shown in Table 4. There was no significant difference $(p=0.62)$ in the initial BW between goat fed with OPB, CNT or COM diets, indicating homogeneity in the weight of animals used in this study. The feeding of OPB, CNT and COM on goats had no significant effect $(p=0.93)$ on the final BW of Katjang goat at the end of feeding trial. Overall, all treatment groups showed no significant difference $(p=0.51)$ in $\mathrm{BW}$ increment, which was from $14.1-20.9 \mathrm{~kg}(48.23 \%), 13.2-20.4 \mathrm{~kg}(54.54 \%)$ and $14.0-20.6 \mathrm{~kg}(47.14 \%)$ for OPB, CNT and COM, respectively. The ADG was also not significantly different $(p=0.94)$ between treatment groups. Although there was no significant difference, ADG of OPB group was numerically higher (68.88 $\left.\mathrm{g} \mathrm{day}^{-1}\right)$ than goats in the COM group (66.84 $\mathrm{g} \mathrm{day}^{-1}$ ), but lower than goats in the CNT group (72.96 $\left.\mathrm{g} \mathrm{day}^{-1}\right)$. The findings suggest that it is possible to incorporate OPB into goat's feed without negatively affecting the growth performance of the goats. Isocaloric and isonitrogenous content among OPB, CNT and COM treatments might be the reason for the acceptable growth performance of the Katjang goat. The result was in agreement with findings by Haryanto (2011), Rahman et al. (2013) and Ebrahimi et al. (2015). Haryanto (2011) reported that Ettawah crossbred goats fed with molasses protected PKC based diet was able to gain up to $70.24 \mathrm{~g} \mathrm{day}^{-1}$ in BW. Rahman et al. (2013) observed Boer x local crossbred goats fed with $2 \%$ BW of PKC based concentrate diets gained $52.5 \mathrm{~g} \mathrm{day}^{-1}$ of BW. Meanwhile, study by Ebrahimi et al. (2015) showed that $25 \%$ of OPF inclusion in male Katjang crossbred goats diet resulted in ADG of $75.71 \mathrm{~g} \mathrm{day}^{-1}$.

No significant differences ( $p>0.05)$ were observed for the dry matter intake (DMI) of the pellet, Napier grass and the diet as a whole (Table 5). However, OPB group had the highest total DMI with $572.54 \mathrm{~g} \mathrm{day}^{-1}$, followed by CNT and COM groups, with 572.33 and $548.41 \mathrm{~g} \mathrm{day}^{-1}$, respectively. The DMI (\% BW) of goat fed with OPB pellet at $3.11 \% \mathrm{BW}$, which is within the requirement for goat in tropical regions, reported to range from 3.0\%-3.66\% BW (Devendra and McLeroy, 1982; Ashok and Wadhwani, 1992). The good DMI (\% BW) indicates the inclusion of oil palm by-products into goat pellet did not give negative effect on the FI of the animals and the pellet was well accepted by the goats.

Yusuf et al. (2014) suggested that animals FI is influenced by several factors, such as diet composition, availability and palatability of the feed. Abubakr et al. (2013) reported that oil palm by-products such as PKC are usually considered as unpalatable feed. However, the current study has shown that inclusion of oil palm by-products up to $49.6 \%$ did not affect the animal FI, suggesting that the palatability might have been improved by processing the feed materials into pellet form. According to Leng (1990); Joo et al. (2012); Abubakr et al. (2013) and Karimizadeh et al. (2017), the FI can be improved through various processing techniques and supplementation. For example, Joo et al. (2012) suggested that feeding a combination of Napier and OPF to goats offer better results in certain aspects compared to the feeding of Napier grass or OPF alone, besides reducing feed cost and environmental waste. Thus, the results of this current study indicate that oil palm by-products based pellet provides adequate nutrients for goats to support their growth.

\section{Carcass Traits and Composition}

Carcass traits and composition of goats fed with different pellets are shown in Table 6 . There were no significant differences $(p>0.05)$ in carcass traits between goats fed with OPB, CNT and COM. Overall, the slaughter weight of goat from all treatments ranged between $19.00-19.55 \mathrm{~kg}$, whereas hot and cold carcass weights were between 8.10$9.13 \mathrm{~kg}$ and $8.00-8.98 \mathrm{~kg}$, respectively. The lowest dressing percentage was observed in goat fed with CNT at $43.84 \%$, which is slightly lower than general dressing percentage of $45 \%-50 \%$ for male goats as reported by Raghavan (1988). However, dressing 
percentage result in this study was within the range (37\%-55\%) as reported by Ensminger (2002).

The goats fed with OPB had no significant differences $(p>0.05)$ on carcass composition such as meat, bone and fat percentage when compared with that of CNT and COM. These results showed that feeding the goats with oil palm by-products did not negatively affect the carcass composition. One of the plausible reasons is because of the similar intake of isocaloric and isonitrogenous feed between OPB, COM and CNT. There was no significant difference in growth performances thus, resulting in similar carcass weight at the end of the feeding period. This finding was consistent with the observation by Ebrahimi et al. (2013) who reported that feeding $25 \%$ oil palm by-products in the diet had no effect on the carcass yield when compared to the group fed with $100 \%$ commercial pellet. Abubakr et al. (2013) also reported that feeding goats with oil palm by-products did not significantly affect the dressing percentage and meat percentage of goats.

TABLE 3. PROXIMATE COMPOSITION OF OIL PALM BY-PRODUCTS BASED, CONTROL AND COMMERCIAL PELLETS

\begin{tabular}{lccc}
\hline Proximate analysis & OPB & CNT & COM \\
\hline Dry matter (DM) & 90.58 & 87.89 & 87.37 \\
Moisture content $(\% \mathrm{DM})^{\mathrm{a}}$ & 9.42 & 12.11 & 12.63 \\
Ash $(\% \mathrm{DM})$ & 7.74 & 10.72 & 6.90 \\
Organic matter $(\% \mathrm{DM})^{\mathrm{a}}$ & 92.26 & 89.28 & 93.10 \\
Crude fat $(\% \mathrm{DM})$ & 4.36 & 5.59 & 4.00 \\
Crude protein $(\% \mathrm{DM})$ & 15.58 & 16.16 & 16.01 \\
Crude fibre $(\% \mathrm{DM})$ & 21.66 & 16.76 & 13.56 \\
Nitrogen free extract $(\mathrm{NFE})(\%)^{\mathrm{a}}$ & 41.25 & 38.65 & 46.91 \\
Gross energy (cal g-1) & 3954 & 3858 & 3933 \\
\hline
\end{tabular}

Note: OPB - oil palm by-products based formulated pellet; CNT - pellet without oil palm by-product inclusion; COM - commercial pellet.

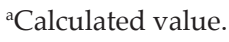

Moisture content $=100-$ dry matter.

Organic matter $=100-$ ash .

Nitrogen free extract $(\%)=100 \%-($ moisture $\%+$ ash $\%+$ crude fat $\%+$ crude protein $\%+$ crude fibre $\%)$

TABLE 4. GROWTH PERFORMANCE OF KATJANG GOATS FED WITH OIL PALM BY-PRODUCTS BASED, CONTROL AND COMMERCIAL PELLETS

\begin{tabular}{lcccc}
\hline Parameter & OPB & CNT & COM & $p$-value \\
\hline Initial body weight $(\mathrm{kg})$ & $14.10 \pm 1.27$ & $13.20 \pm 1.40$ & $14.00 \pm 0.75$ & 0.62 \\
Final body weight $(\mathrm{kg})$ & $20.90 \pm 1.33$ & $20.40 \pm 2.18$ & $20.60 \pm 1.75$ & 0.93 \\
Total body weight gain $(\mathrm{kg})$ & $6.80 \pm 1.28$ & $7.20 \pm 1.33$ & $6.60 \pm 1.37$ & 0.51 \\
Average daily gain $\left(\mathrm{g} \mathrm{day}^{-1}\right)$ & $68.88 \pm 13.05$ & $72.96 \pm 13.58$ & $66.84 \pm 13.98$ & 0.94 \\
\hline
\end{tabular}

Note: OPB - oil palm by-products based formulated pellet; CNT - pellet without oil palm by-product inclusion; COM - commercial pellet.

Values shown are means \pm s.d. $(n=4)$.

TABLE 5. FEED INTAKE OF KATJANG GOATS FED WITH OIL PALM BY-PRODUCTS BASED CONTROL AND COMMERCIAL PELLETS

\begin{tabular}{lcccc}
\hline Parameter & OPB & CNT & COM & $p$-value \\
\hline Pellet DMI $\left(\mathrm{g} \mathrm{day}^{-1}\right)$ & $252.43 \pm 0.00$ & $252.43 \pm 0.00$ & $250.55 \pm 2.17$ & 0.46 \\
Napier DMI $\left(\mathrm{g} \mathrm{day}^{-1}\right)$ & $322.83 \pm 0.29$ & $319.90 \pm 3.63$ & $311.34 \pm 13.43$ & 0.17 \\
Total DMI $\left(\mathrm{g} \mathrm{day}^{-1}\right)$ & $572.54 \pm 0.29$ & $572.33 \pm 3.63$ & $548.41 \pm 15.60$ & 0.54 \\
DMI $(\% \mathrm{BW})$ & $3.11 \pm 0.20$ & $3.27 \pm 0.31$ & $3.13 \pm 0.21$ & 0.61 \\
\hline
\end{tabular}

Note: OPB - oil palm by-products based formulated pellet; CNT - pellet without oil palm by-product inclusion; COM - commercial pellet; DMI - dry matter intake; BW - body weight.

Values shown are means \pm s.d. $(n=4)$. 
TABLE 6. CARCASS TRAITS AND COMPOSITION IN KATJANG GOATS FED WITH OIL PALM BYPRODUCTS BASED, CONTROL AND COMMERCIAL PELLETS

\begin{tabular}{|c|c|c|c|c|}
\hline Parameter & OPB & CNT & COM & $p$-value \\
\hline \multicolumn{5}{|l|}{ Carcass traits } \\
\hline Slaughter weight (kg) & $19.55 \pm 1.24$ & $19.00 \pm 2.11$ & $19.40 \pm 1.66$ & 0.90 \\
\hline Hot carcass weight (kg) & $9.13 \pm 1.11$ & $8.10 \pm 1.05$ & $9.10 \pm 0.80$ & 0.37 \\
\hline Cold carcass weight (kg) & $8.97 \pm 1.06$ & $8.00 \pm 1.05$ & $8.98 \pm 0.81$ & 0.39 \\
\hline Dressing percentage $(\%)$ & $46.81 \pm 2.06$ & $43.84 \pm 1.60$ & $47.04 \pm 4.12$ & 0.38 \\
\hline 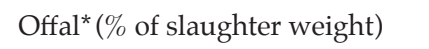 & $21.20 \pm 1.10$ & $20.50 \pm 1.77$ & $20.93 \pm 1.58$ & 0.85 \\
\hline Pluck $^{\#}$ (\% of hot carcass weight) & $5.82 \pm 0.46$ & $6.52 \pm 0.97$ & $6.50 \pm 0.78$ & 0.46 \\
\hline \multicolumn{5}{|l|}{$\begin{array}{l}\text { Carcass composition } \\
\text { (\% of cold carcass weight) }\end{array}$} \\
\hline Meat & $66.14 \pm 1.13$ & $66.84 \pm 2.50$ & $68.19 \pm 4.10$ & 0.68 \\
\hline Bone & $22.94 \pm 2.17$ & $21.66 \pm 1.66$ & $22.07 \pm 1.42$ & 0.66 \\
\hline Fat & $10.92 \pm 3.28$ & $11.50 \pm 2.34$ & $9.74 \pm 2.86$ & 0.76 \\
\hline Meat:bone & $2.90 \pm 0.23$ & $3.10 \pm 0.30$ & $3.11 \pm 0.37$ & 0.65 \\
\hline Meat: fat & $6.51 \pm 2.28$ & $6.03 \pm 1.58$ & $7.57 \pm 2.59$ & 0.66 \\
\hline
\end{tabular}

Note: OPB - oil palm by-products based formulated pellet; CNT - pellet without oil palm by-product inclusion; COM - commercial pellet; Offal* - head, leg and skin; Pluck ${ }^{\#}$ - heart, liver, kidney, lungs and spleen. Values shown are means \pm s.d. $(n=4)$.

\section{CONCLUSION}

The growth performance and carcass quality of Katjang goats fed with oil palm by-products based pellet were comparable to goats fed with formulated control pellet, as well as those fed with the commercial pellet. The inclusion of oil palm byproducts ingredients in goat pellets did not have any adverse effect on the palatability of the pellet. Therefore, oil palm by-products can be included in the feed formulation without compromising the growth performance and carcass composition of Katjang goats.

\section{ACKNOWLEDGEMENT}

The authors would like to thank the DirectorGeneral of MPOB for permission to publish this article. Appreciation also goes to the staffs of Energy and Protein Centre Group and Protein and Food Technology Unit for their assistance in ensuring the success of this study.

\section{REFERENCES}

Abdullah, N and Sulaiman, F (2013). The oil palm wastes in Malaysia. Biomass Now - Sustainable Growth and Use (Matovic, M D ed.). InTech, Croatia. http: / / www.intechopen.com/books/biomass-nowsustainable-growth-and-use / the-oil-palm-wastesin-malaysia, accessed on 7 December 2017.

Abubakr, A R; Alimon, A R; Yaakub, H; Abdullah, $\mathrm{N}$ and Ivan, M (2013). Growth, nitrogen metabolism and carcass composition of goats fed palm oil byproducts. Small Rumin. Res., 112(1-3): 91-96.

Alimon, A R (2004). The nutritive value of palm kernel cake for animal feed. Palm Oil Developments, 40(1): 12-14.

Aliyu-Paiko, M and Hashim, R (2012). Effects of substituting dietary fish oil with crude palm oil and palm fatty acid distillate on growth, muscle fatty acid composition and the activities of hepatic lipogenic enzymes in snakehead (Channa striatus, Bloch 1793) fingerling. Aquac. Res., 43(5): 767-776.

Association of Official Analytical Chemists (1990). Official Methods of Analysis of the AOAC. $15^{\text {th }}$ Edition. Analytical Chemists, Arlington, USA. 771 pp.

Ashok, M P and Wadhwani, K N (1992). Feedlot performance of Marwari kids on rations with varying proportion of concentrate and roughages. Proc. of the International Conference on Goats. New Delhi, India. p. 835-838.

Department of Standard Malaysia (2009). MS1500:2009: Halal food production, preparation, handling and storage - General guidelines (second revision) Malaysia.

Devendra, C and Mcleroy, G B (1982). Nutrient requirement of goats. Goat and Sheep Production in the Tropics. Longman, London. $271 \mathrm{pp}$.

DVS (2018). Livestock Statistics. http:/ / www.dvs. gov.my/index.php/pages/view/1498, accessed on 30 October 2018. 
Ebrahimi, M; Rajion, M A; Meng, G Y; Shokryzadan, P; Sazili, A Q and Jahromi, M F (2015). Feeding oil palm (Elaeis guineensis Jacq.) fronds alters rumen protozoal population and ruminal fermentation pattern in goats. Ital. J. Anim. Sci., 14(3): 402-409.

Ebrahimi, M; Rajion, M A; Goh, Y M; Sazili, A Q; Soleimani, A F and Schonewille, J T (2013). Oil palm (Elaeis guineensis Jacq.) frond feeding of goats in the humid tropics. J. Anim. Vet. Adv., 12(4): 431-438.

Ensminger, M E (2002). Sheep and Goat Science, $6^{\text {th }}$ edition. Interstate Publisher, lllinois, USA. 693 pp.

Fereira, A C; Ronaldo, L O; Adriana, R B; Gleidson, G P D C; Raimundo, N V S and Paulo, A O (2012). Intake, digestibility and intake behaviour in cattle fed different levels of palm kernel cake. Revista MVZ Córdoba, 17(3): 3105-3112.

Ginting, S P; Simanihuruk, K; Tarigan, A and Pond, K R (2018). Nutritional support for small ruminant development based on oil palm by-products. WARTAZOA. Indonesian Bulletin of Animal and Veterinary Sciences, 28(4): 189-198.

Haryanto, B (2011). Molasses protected palm kernel cake as source of protein for young male Ettawah Grade goats. Indonesian J. Animal and Veterinary Sciences, 16(1): 17-24.

Hosseini, S E; Wahid, M A and Ganjehkaviri, A (2015). An overview of renewable hydrogen production from thermochemical process of oil palm solid waste in Malaysia. Energy Convers. Manag., 94: 415-429.

Joo, W M; Rajion, A; Ping, L Z; Ebrahimi, $M$ and Meng, G Y (2012). In vitro evaluation of Napier grass-oil palm frond combination as ruminant feed. Proc. of the $7^{\text {th }}$ Seminar in Veterinary Sciences. Universiti Putra Malaysia. p. 68-72.

Karimizadeh, E; Chaji, $\mathrm{M}$ and Mohammadabadi, T (2017). Effects of physical form of diet on nutrient digestibility, rumen fermentation, rumination, growth performance and protozoa population of finishing lambs. Anim. Nutr., 3(2): 139-144.

Kushairi, A; Loh, S K; Azman, I; Hishamuddin, E; Ong-Abdullah, M; Izuddin, Z B M N; Razmah, G; Sundram, S and Parveez, G K A (2018). Oil palm economic performance in Malaysia and R\&D progress in 2017. J. Oil Palm Res., 30(2): 163-195.

Leng, R A (1990). Factors affecting the utilization of 'poor-quality' forages by ruminants particularly under tropical conditions. Nutr. Res. Rev., 3(1): 277303.
McDonald, P; Edwards, R A; Greenhalgh, J F D; Morgan, C A; Sinclair, L A and Wilkinson, R G (2010). Animal Nutrition, $7^{\text {th }}$ edition. Pearson Education, United Kingdom. 714 pp.

Meat and Livestock Australia (2018). The Malaysian market. https: / / www.mla.com.au/prices-markets / market-news / in-depth-sheep-and-goat-meat-tomalaysia/, accessed on 29 November 2018.

MPOB (2016). MPOB Annual Report. https:// parlimen.gov.my / ipms / eps / 2017-11-30 / ST.154.2017\%20-\%20MPOB.pdf, accessed on 6 January 2020.

MPOB (2018). Overview of the Malaysian oil palm industry 2017. http://palmoilis.mpob.gov.my/ index.php / overview-of-industry / 593-overviewof-industry-2017, accessed on 15 October 2019.

Ministry of Agriculture and Food Industries Malaysia (2016). Agrofood Statistics. http:// www.moa.gov.my / documents / 20182 / 29034 / Perangkaan+Agromakanan+2016_new-min.pdf / fbaac259-7f29-422e-ab5d-02d5f7d79718, accessed on 30 November 2018.

Mohamed, W Z; Alimon, A R and Wong, H K (2012). Chapter 13: Utilization of oil palm co-products as feeds for livestock in Malaysia. Biofuel CoProducts as Livestock Feed (Makkar, H ed.). Food and Agriculture Organization of the United Nations, Rome. p. 243-262.

National Research Council (1981). Nutrient Requirements of Goats: Angora, Dairy, and Meat Goats in Temperate and Tropical Countries. First edition, Vol. 15. National Academies Press, Washington. $90 \mathrm{pp}$.

Palmquist, D L (2004). Palm fats for livestock feeding. Palm Oil Developments, 40: 10-16.

Pimentel, L R; da Silva, F F; Silva, R R; Schio, A R; de Oliveira Rodrigues, E S and de Oliveira, P A (2015). Feeding behavior of lactating cows fed palm kernel cake in the diet. Acta Sci., 37(1): 83-89.

Raghavan, G V (1988). Influence of sex on goat meat production. Goat Meat Production in Asia: Proc. of the Workshop Held in Tando Jam, Pakistan. 13-18 March 1988. IDRC, Ottawa, ON, CA.

Rahman, M M; Abdullah, R B; Wan Khadijah, W E; Nakagawa, T and Akashi, R (2013). Effect of palm kernel cake as protein source in concentrate diet on intake, digestibility and live weight gain of goats fed Napier grass. Trop. Anim. Health Prod., 45(3): 873-878. 
Rodriguez, L and Preston, T R (1997). Local feed resources and indigenous breeds: Fundamental issues in integrated farming systems. Livest. Res. Rural Dev., 9(2): 92-99.

Sontakke, U; Kale, V; Bose, B and Kumar, M (2014). Non-conventional feeds and agro industrial by products: Their scope and future demand for livestock production. https://en.engormix.com/ feed-machinery / articles / non-conventional-feedsagro-t36183.htm, accessed on 5 September 2018.

Sudaryanto, T (2017). Palm oil and beef cattle integration system: A strategy to accelerate beef production in Indonesia. http://ap.fftc.agnet. org /ap_db.php?id=732\&print $=1$, accessed on 5 September 2019.

Tipu, M A; Ahmad, F; Khalique, A; Haque, M N; Mirza, R H and Tayyab, U (2014). Replacement of cotton seed cake with palm kernel cake in growing nili-ravi buffalo male calves. J. Anim. Plant Sci., 24(1): 24-27.

Tomkins, T and Drackley, J K (2010). Applications of palm oil in animal nutrition. J. Oil Palm Res., 22(3): 835-845.

Yusuf, A L; Goh, Y M; Samsudin, A A; Alimon, A R and Sazili, A Q (2014). Growth performance, carcass characteristics and meat yield of boer goats fed diets containing leaves or whole parts of Andrographis paniculata. Asian-Australas. J. Anim. Sci., 27(4): 503-510.

Zahari, M W and Alimon, A R (2005). Use of palm kernel cake and oil palm by-products in compound feed. Palm Oil Developments, 40: 5-8.

Zahari, M W; Abu Hassan, O; Wong, H K and Liang, J B (2003). Utilization of oil palm frond-based diets for beef and dairy production in Malaysia. AsianAustralas. J. Anim. Sci., 16(4): 625-634. 